
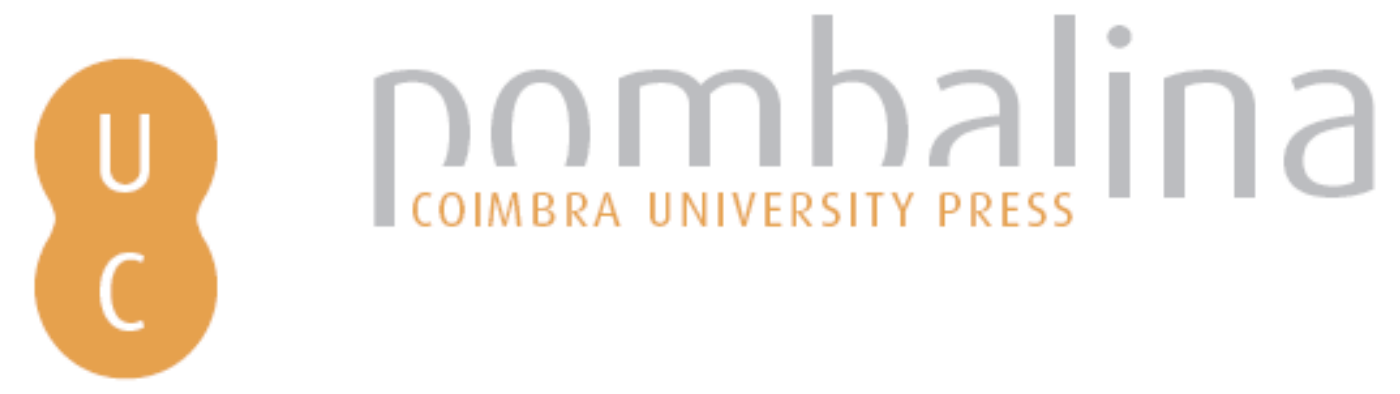

\title{
Fire in wet eucalypt forests: rethinking fuel-accumulation models for Tasmania's most unique fuel type
}

Autor(es): $\quad$ Furlaud, J. M.; Bowman, D. M. J. S.

Publicado por: Imprensa da Universidade de Coimbra

URL

persistente: URI:http://hdl.handle.net/10316.2/44661

DOI: DOI:https://doi.org/10.14195/978-989-26-16-506_144

Accessed : $\quad$ 26-Apr-2023 09:39:37

A navegação consulta e descarregamento dos títulos inseridos nas Bibliotecas Digitais UC Digitalis, UC Pombalina e UC Impactum, pressupõem a aceitação plena e sem reservas dos Termos e Condições de Uso destas Bibliotecas Digitais, disponíveis em https://digitalis.uc.pt/pt-pt/termos.

Conforme exposto nos referidos Termos e Condições de Uso, o descarregamento de títulos de acesso restrito requer uma licença válida de autorização devendo o utilizador aceder ao(s) documento(s) a partir de um endereço de IP da instituição detentora da supramencionada licença.

Ao utilizador é apenas permitido o descarregamento para uso pessoal, pelo que o emprego do(s) título(s) descarregado(s) para outro fim, designadamente comercial, carece de autorização do respetivo autor ou editor da obra.

Na medida em que todas as obras da UC Digitalis se encontram protegidas pelo Código do Direito de Autor e Direitos Conexos e demais legislação aplicável, toda a cópia, parcial ou total, deste documento, nos casos em que é legalmente admitida, deverá conter ou fazer-se acompanhar por este aviso.

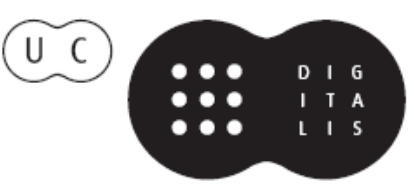




\section{ADVANCES IN}

\section{FOREST FIRE RESEARCH}

\section{8}

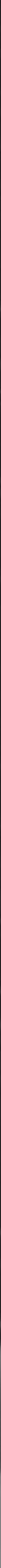


Short contribution - Fuel Management

Fire in wet eucalypt forests: rethinking fuel-accumulation models for Tasmania's most unique fuel type

\author{
J. M. Furlaud* and D. M. J. S. Bowman \\ School of Biological Sciences, University of Tasmania, Hobart, Tasmania, Australia, \\ \{james.furlaud@utas.edu.au*\}
}

Keywords: fuel accumulation, fuel loads, temperate rainforests, sclerophyllous forests, wet eucalypt forests, fire hazard, chronosequence, macro-ecological gradients, climate change

\title{
1. Introduction
}

Wet eucalypt forests are potentially the most dangerous fuel type in Tasmania, an island state in Australia's temperate southeast. Their long fire return interval (sometimes hundreds of years) allows for massive accumulation of fuels that could potentially result in the highest fire intensities on Earth. However, there is little empirical data describing fuel loads in these forests, especially in Tasmania, where current fire behaviour models are calibrated using data from ecologically-distinct Victorian forests. Understanding how these fuels accumulate over time is critical for calibrating fire behaviour models for this fuel type.

\section{Methods}

We measured fuels along a chronosequence of 24 plots in southeast Tasmanian wet eucalypt forests, ranging from recently-burnt to old-growth forests. In each plot we measured the structure and finefuel biomass in tonnes per hectare (t/ha) of the surface fuels, elevated fuels, and canopy bark. We also recorded qualitative fire-hazard scores and measured temperature and humidity of the understorey climate. With this data, we developed novel fuel-accumulation models to describe fuel loads and fire danger as a function of time since previous fire. We also measured fuels across the TERN Ausplots Forest Monitoring Network: 48 permanent plots in mature tall wet eucalypt forests across a variety of Australian climates. This provided insight into how the structure and fuel load might change in Tasmania's forests as the climate warms.

\section{Results \& Discussion}

In developing novel fuel-accumulation models for Tasmania's wet eucalypt forests, we found that, even though overall fuel biomass continues to increase as a forest ages, the trends in fuel hazard in the different layers are substantially more complex. In general, however, it appears that while fuel hazard increases, sometimes dramatically so, directly after a fire, it decreases as a forest matures into old growth forest (Figure 1). Additionally, after mid-successional stages, the composition of the understorey (i.e. the elevated fuel layer) shifts from moderately-flammable sclerophyllous species to less-flammable rainforest species. This shift is not represented in the hazard scores, suggesting that the reduction in flammability in mature forest understoreys is even greater than is indicated by Figure 1. Additionally, our understorey temperature and humidity measurements indicate that as the forest ages, and the canopy closes, a cooler and moister microclimate develops (Figure 2), further reducing fire hazard. Analysing the data from our continental-scale 

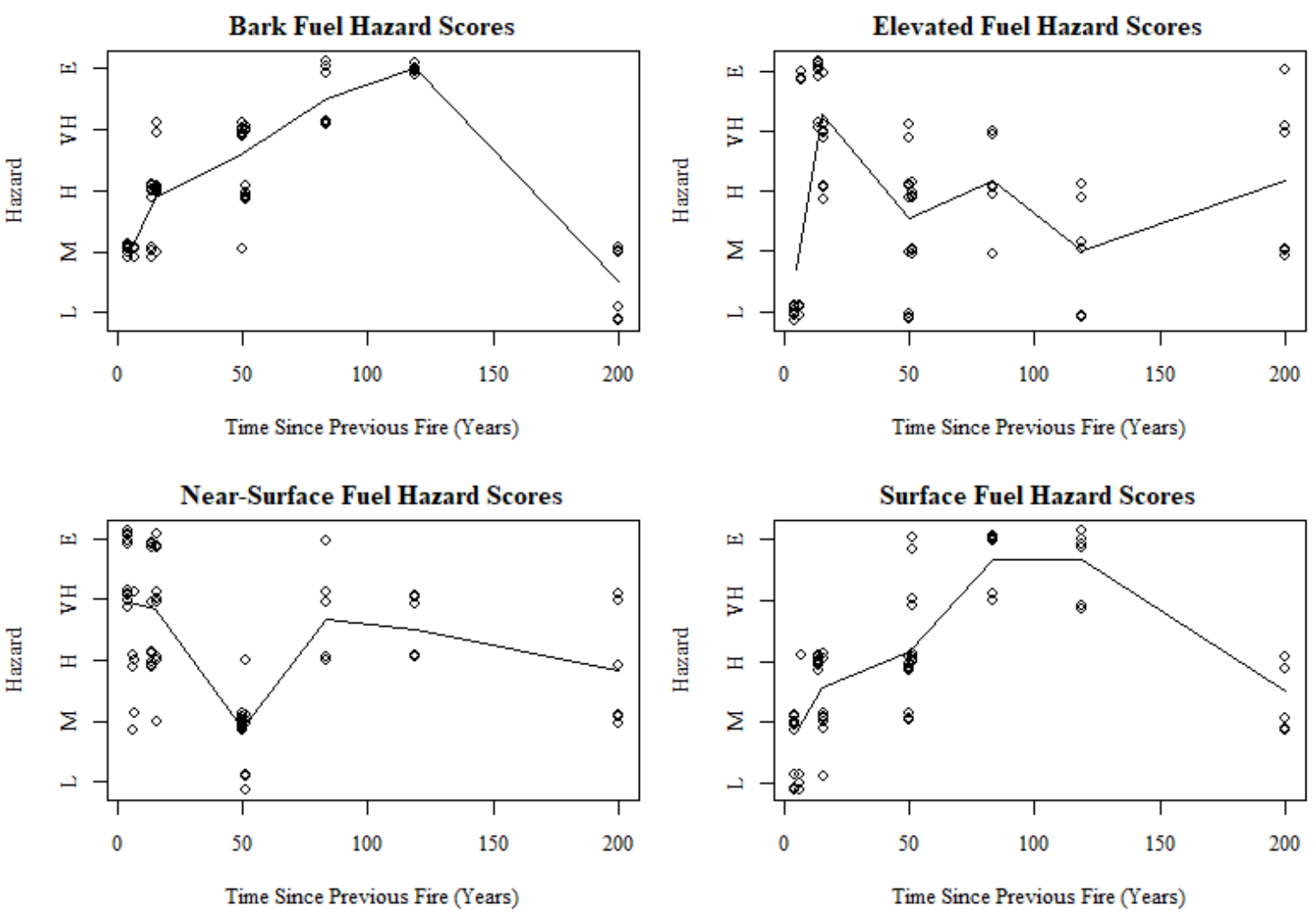

Figure 1 - Qualitative hazard scores, as used by local fire agencies, plotted against stand age, as measured by time since previous fire for each of the chronosequence plots. Hazard scores are presented for the bark, elevated, nearsurface, and surface fuel layers. The black line represents the trend for the mean hazard score for each age class.

Hazard score abbreviations are as follows: L-Low, M-Moderate, H-High, VH-Very High, E-Extreme.

(a)

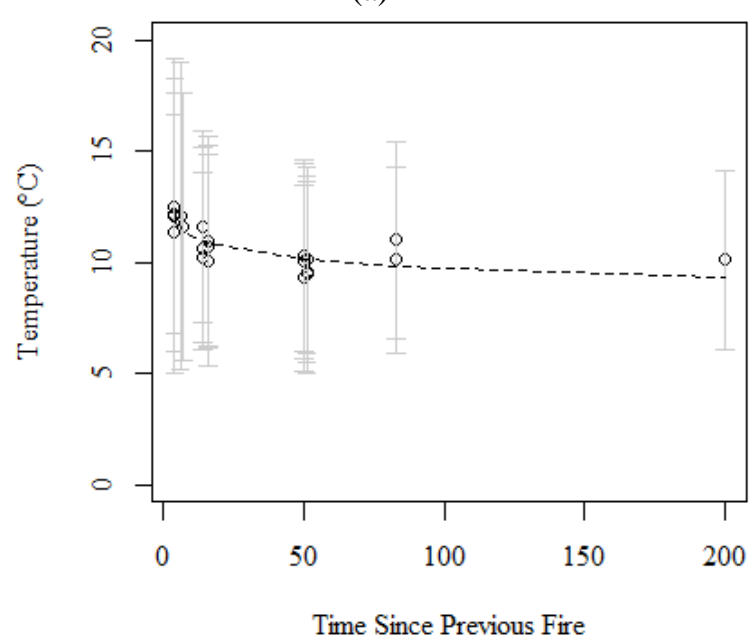

(b)

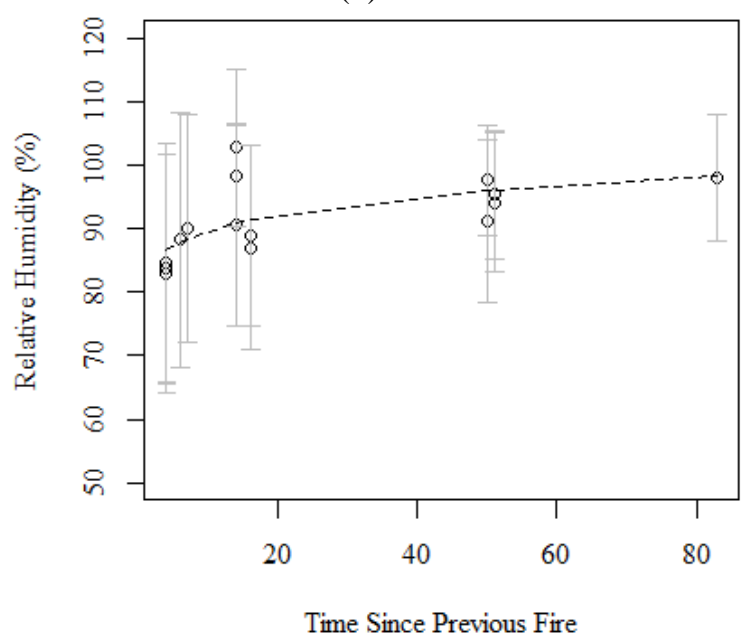

Figure 2 - Mean temperature (a) and relative humidity (b) in the understorey, as measured by data loggers, plotted against time since previous fire for each of the chronosequence plots. Dots represent the mean of measurements from the six-month period between August 2016 and January 2017. Grey bars represent one standard deviation. The dashed line represents the best-fit line according to a generalised linear model.

Ausplots Forest Monitoring Network, we found fuel biomass and structure in each layer to be highly variable across different climates. Generally speaking, warmer climates appear to support forests with 
more continuous vertical fuel structure and more regular crown fires. This could suggest that climate change will alter the structure, and hence the fire regime of Tasmania's wet eucalypt forests, however a more detailed analysis is required. Perhaps more importantly, we found the vertical structure of these fuels to be highly complex along both chronological and climatic gradients. This is problematic as fire behaviour models currently treat fuel load as a singular mass. Our research suggests a need for a more multifaceted representation of fuel loads in these models. 